\title{
ANALISIS PENGARUH PENGUMUMAN BOND RATING TERHADAP RETURN SAHAM PERUSAHAAN DI BURSA EFEK JAKARTA PERIODE 2012-2014
}

\author{
Rinto Noviantoro \\ Program Studi Manajemen \\ Universitas Dehasen Bengkulu
}

\begin{abstract}
ABSTRAK
Rinto Noviantoro: Tujuan penelitian ini untuk menguji mengenai dampak dari pengumuman bond rating terhadap return saham sebelum (pengumuman bond rating), pada saat (pengumuman bond rating), dan sesudah (pengumuman bond rating). Data yang digunakan adalah data return saham sehari-hari yang diperoleh dari Bursa Efek Jakarta Bond rating diumumkan oleh PT. PEFINDO, dn data perusahaan yang digunakan telah terdaftar di Bursa efek jakarta antara tahun 2012 sampai 2014. Sampel penelitian sebanyak 29 perusahaan diambil berdasarkan purposive sampling. Data ini dianalisis dengan menggunakan paired sample t-tes dan ANOVA.

Dari penelitian di simpulkan bahwa : (1) tidak ada perbedaan yang signifikan antara return saham pada tanggal pengumuman bond rating dengan hari-hari sebelum pengumuman bond rating (2) tidak ada perbedaan yang signifikan antara return saham pada tanggal pengumuman bond rating dengan hari-hari sesudah pengumuman bond rating (3) ada perbedaan yang signifikan antara return saham antara sebelum pengumuman dan sesudah pengumuman bondrating (4) rata-rata return saham pada saat hari (pengumuman), sebelum dan setelah pengumuman bond rating tidak ada perbedaan yang signifikan.
\end{abstract}

\begin{abstract}
Rinto Noviantoro: The purpose of this study to examine the impact of the announcement of bond rating on stock returns prior (the announcement of bond rating), stock return on day (bond rating announcement). Data used are daily stock return by Jakarta Stock Exchange (JSE), bond rating announcement by PT. PEFINDO, and firm are listing in Jakarta Stock Ekchange between 2012 to 2014. This research using 29 emitens as the sample bosed on purposive sampling. This data are analyzed with paired sample t-test and Oneway ANOVA.

The analysis indicates that: (1) the defference are not significant between stock return an day bond rating announcement with before day bond rating announcement, (2) the difference are not significant between stock return on day bond rating announcement with after day bond rating announcement, (3) the difference are significant between stock return before bond rating announcement with after bond announcement (4) avarage stock return on day, before and after bond rating announcement are not significant differences.
\end{abstract}

Key words: Obligasi, Return Saham

\section{PENDAHULUAN}

Telah banyak wahana investasi yang ditawarkan di zaman moderen ini. Secara garis besar lahan investasi seperti investasi keuangan yaitu investasi dalam bentuk surat-surat berharga. Salah satunya ialah lahan investasi yang sedang marak akhir-akhir ini adalah investasi pada pasar modal.

Pasar modal memiliki peran yang sangat penting dalam perekonomian suatu negara. Keberadaan pasar modal merupakan salah satu sumber pembiayaan yang berasal dari dalam negri untuk pelaksanaan kegiatan pembanggunan indonesia. Keberadaan pasar modal indonesia merupakan suatu bentuk pasarkeuangan yang menjadi perhatian banyak pihak, khususnya masyarakat bisnis. Hal ini terutama dikarenakan oleh kegiatan pasar modal yang semakin berkembang dan efisien bagi beberapa pihak seperti para investor. Pasar modal merupakan bagian dari pasar keuangan, yang menjalankan fungsi ekonomi dan keuangan. Fungsi ekonomi yang dijalankan pasar modal melibatkan 2 pihak yaitu pihak kelebihan dana dan pihak yang membutuhkan dana. Fungsi keuangan ditunjukan dengan kemungkinan memperoleh imbalan (return) bagi pihak pemilik dana, sesuai dengan karakteristik yang dipilih. Bagi pihak yang 
membutuhkan dana, tersediahnya dana dari pihak luar memungkinkan perusahaan untuk melakukan investasi tanpa harus menunggu tersedianya dana dari hasil operasi perusahaan.

Obligasi merupakan salah satu surat berharga yang diperdagangkan dipasar modal. Obligasi termasuk salah satu jenis surat berhaga pendapatan tetap atau yang disebut dengan fixed income securities. Dimana definisi obligasi itu sendiri adalah surat berharga tanda hutang dari pihak yang menerbitkan (issue) kepada investor sebagai pembeli. Biasanya suatu obligasi sebelum ditawarkan kepada publik (masyarakat pemodal) diperingat terlebih dahulu oleh lembaga pemerintah terkait. Lembaga pemerintah yang melakukan pemeringatan tersebut yang ada di indonesia adalah PT Pemeringat Efek Indonesia (PT PEFINDO) yang juga bekerja sama dengan standard \& poor's. Obligasi yang layak dibeli adalah obligasi yang memiliki peringkat investment grade atau diatas rating B. Semakin tinggi rating semakin kecil resiko obligasi tersebut. Obligasi merupakan hutang bukan ekuitas yang mampu memperbaiki struktur keuangan perusahaan. Jika hutang tidak diimbangi dengan membaiknya kinerja perusahaan, maka akan terjadi bahaya default.

Tujuan dari pemeringkatan obligasi (bond rating) adalah untuk menilai kinerja perusahaan dari berbagai faktor baik secara langsung maupun tidak langsung yang terkait dengan keuangan perusahaan. Pemeringkatan (rating) yang diberikan oleh lembaga pemeringkat yaitu PT Pemeringkat Efek Indonesia (PT PEFINDO) akan menyatakan apakah obligasi tersebut layak atau tidak untuk investasi. Dengan adanya pemeringkatan (rating) tersebut dapat dinilai apakah perusahaan nantinya mampu atau tidak mampu membayar hutangnya sesuai dengan penilaian Lembaga Pemeringkat (PT PEFINDO). Dengan adanya pemeringkatan obligasi (bond rating) tersebut akan membantu investor dalam memilihinvestasinya, sehingga investor tidak perluh lagi melakukan proses evaluasi, yaitu dengan melakukan survey terlebih dahulu untuk melakukan investasi. Lembaga Pemeringkat obligasi (bond rating) tersebut untuk memberikan informasi yang objektif kepada masyarakat tentang perkembangan instrument investasi.

Informasi yang berupa pengumuman bond rating tersebut akan menimbulkan reaksi dari para pelaku pasar modal. Pelaku pasar modal akan bereaksi pada waktu sebelum, pada saat pengumuman dan setelah pengumuman bond rating dipublikasikan. Untuk mengetahuireaksi dari pemodal karena adanya pengumuman bond rating dapat diamati pada return saham.

Return saham diasumsikan mengalami perubahan ketika ada informasi baru dan diserap oleh pasar. Apabila para pemodal menggunakan informasi yang berupa pengumuman bond rating dalam kegiatanya, maka publikasi pengumuman bond rating akan memberikan dampak berupa return saham apabila di bandingkan dengan hari-hari diluar pengumuman. Oleh karena itu penulis ingin meniliti dan menguji kembali hasil penelitian yang telah dilakukan oleh Hand, Holthausen dan Lefwithch (1992), Griffin dan Sanvicente (1982), Goh dan Ederington (1998) yang menunjukan bahwa penurunan peringkat hutang merupakan informasi yang buruk bagi Shareholder dan Bondholder, tetapi peningkatan peringkat hutang hanya memberikan informasi yang rendah bagi return saham, kecuali kalau pengumuman tersebut disampaikan secara terbuka pada pasar yang kemudian direspon oleh publik. Adanya kandungan dari informasi akuntansi dapat dilihat dari reaksi investor dalam pasar modal. Investor dalam pasar modal akan bereaksi ketika suatu informasi baru masuk kepasar. Informasi bagi investor sehingga pasar tidak bereaksi secara signifikan terhadap return saham, pengumuman bond rating di Indonesia kemungkinan bukan merupakan salah satu faktor penyebab yang dapat mempengaruhi return saham. Investor pada saat ini mengabaikan informasi bond rating dalam melaksanakan aktivitas perdagangan saham, hal ini kemungkinan terjadi karena investor sudah memperkirakan hasil pengumuman bond rating tersebut sesuai dengan prediksi yang di buat oleh investor.

\section{TINJAUAN LITERATUR Pasar Modal}

Pasar modal mempunyai peran strategis sebagai salah satu sumber pembiayaan bagi dunia usaha, termasuk usaha menegah dan kecil untuk membanggun usahanya, sedangkan disisi lain pasar modal juga merupakan wahana investasi bagi masyarakat, termasuk pemodal menegah dan kecil. Untuk dapat melaksanakan peran strategis tersebut pasar modal perlu infrastuktur yang memadai, sikap profesional dari para pelaku yang terlibat didalamnya serta kerangka hukum yang kokoh.

\section{Definisi Pasar Modal}

Definisi pasar modal menurut Drs Irwan Idris Msi (2011:4) “ pasar modal adalah pasar penghubung antara masyarakat yang kelebihan dana dengan masyarakat yang membutuhkan dana (emiten = pihak yang melakukan penawaran umum)". 
Sedangkan menurut Frank J. Fabozzi (2009:15) “ pasar modal adalah pasar keuangan bagi instrumen- instrumen ekuitas dan istrumen-instrumen hutang yang jatuh tempo lebih dari satu tahun"

\section{Pelaku Pasar Modal}

Dimana didalam pasar modal mempunyai pelaku psar modal yang menjalankan investasi keuangan dan dimana menurut Drs Abdul Basith Anwar (2004:28)

\section{Emiten}

Perusahaan yang melakukan emisi, baik berupa saham ataupun obligasi . secara internasional istilah emiten dikenal dengan sebutan "issuer" yang artinya suatu perusahaan yang menerbitkan dan menawarkan efek untuk dijual kepada masyarakat umum.

2. Investor Pemodal yang mempunyai dana lebih untuk membeli efek.

3. Penjaminan emisi (underwriter)

Penjamin emisi efek adalah pihak-pihak yang telah mengadakan perjanjian tertulis (kontrak) dengan emiten untuk memberi efek yang diterbitkan oleh emiten dan selanjutnya dijual kepada masyarakat umum.

4. Agen penjual Pihak yang menjual efek dari perusahaan yang go publik tanpa kontrak dengan emiten yang bersangkutan.

5. Penanggung (Gurantor) Pihak yang menanggung pembayaran jumlah pokok disamping bunga obligasi dalam hal emiten tidak memenuhi janjinya kepada investor.

6. Wali amanat (trustee)

Diperlukan pada emisi obligasi karena wali amanat akan bertindak sebagai pihak yang dipercaya untuk mewakili kepentingan seluruh investor obligasi. Juga berperan sebagai pemimpin dalam rapat umum pemegang obligasi (RUPO)

7. Pialang Pihak lain yang juga melakukan penjualan efek, yang sering disebut dengan nama "broker".

8. Biro Administrasi Efek (BAE)

Pihak lain yang melakukan administrasi saham, jasa-jasanya melipuyi :

a. Pembukuan jumlah efek yang diterbitkan oleh emiten, nomor seri, bilyet, pecahan minimal efek.

b. Pencatatan dan pengalihan / pemindahan nama kepemilikan efek.

c. Pembukuan penawaran "righ issue" yaitu penawaean efek kepada pihak-pihak yang telah memiliki efek yang diterbitkan oleh emiten ,BAPEPAM, BEJ dan pihak lainya.

d. Pembukuan pembayaran deviden tunai dan bonus saham

9. Custodian

Tempat penitipan harta yang berfungsi sebagai perusahaan yang menyelenggarakan penyimpanan harta dalam penitipan untuk kepentingan pihak lain berdasarkan surat perjanjian tertulis (kontrak) harta yang dimaksud adalah surat-surat berharga seperti saham, obligasi dan sertifikat deposito.

\section{Definisi Obligasi}

Secara umum obligasi didefinisikan sebagai efek / sekuritas / surat berharga tanda hutang pendapatan tetap yang diperdagangkan di masyarakat, dimana penerbitnya setuju untuk membayar sejumlah bunga tetap untuk jangka waktu tertentu dan akan membayar kembali jumlah pokoknya padajatuh tempoh.

Menurut Dahlan Slamat (2011:270) "obligasi atau bond adalah merupakan salah satu instrumen keuangan yang cukup menarik bagi kalangan investor dipasar modal ataupun bagi perusahaan untuk mendaptkan dana bagi kepentingan perusahaan ".

Menuru Frank J. Fabozzi (2009:214), obligasi di artikan sebagai "istrumen dimana emitenya (penghutang/peminjam) berjanji untuk membayarkembali jumlah yang dipinjam ditambah bunga kepada investor selama periode waktu tertentu".

Obligasi merupakan surat tanda hutang jangka panjang yang diterbitkan oleh perusahaan ataupun pemerintah. Dengan kata lain obligasi adalah kontrak antara pemberi pinjaman dengan yang diberi pinjaman dan kontrak ini diwujudkan dalam bentuk surat obligasi. jadi, surat obligasi menurut sawidji 
(2010:100) adalah " selembar kertas yang menyatakan bahwa pemilik kertasa tersebut memberikan pinjaman kepada yang diberi pinjaman melalui sebuah kontrak, dan akibat adanya kontrak tersebut pemberi pinjaman memiliki hak untuk dibayar kembali pada waktu tertentu dan dengan jumlah tertentu pulah".

Berdasarkan uraian diatas, dapat dikatakan bahwa obligasi adalah surat berharga tanda hutang dari pihak yang menerbitkanya (issue) kepada invstor sebagai pembeli. Obligasi berbeda dengan saham yang merupakan tanda bukti kepemilikan. Pembayaran penghasilan yang diperoleh pemegang obligasi tidak tegantung sama sekali pada keputusan direksi, sedangkan pembayaran pada pemegang saham preferen hanya bisa dilakukan bila direksi mengambil keputusan untuk pembayaranya.

\section{Tujuan Penerbitan Obligasi}

Penerbit obligasi dilakukan oleh perusahaan yang membutuhkan dana, baik untuk ekspansi bisnis ataupun untuk memenuhi kebutuhan keuangan perusahaan dalam jangka pendek ataupun jangka panjang. Obligasi pada dasarnya merupakan surat hutang yang ditawarkan kepada publik. Apabila investor berminat ia bisa membeli melalui pihak penjamin (underwriter) atau agen penjual lewat penjualan dipasar perdana, atau melalui proker dealer apabila dibeli melalui pasar skunder. Dengan membeli obligasi tersebut, pembeli akan mendapatkan imbalan pendapatan tingkat suku bunga (kupon) yang ditawarkan sebelumnya seperti yang tertulis dalam prospektus obligasi.

Perusahaan yang menerbitkan obligasi memiliki beberapa tujuan penting menurut Rahardjo (2013:10), diantaranya :

a. mendapatkan jumlah dana tambahan yang lebih fleksibel

dengan menerbitkan obligasi maka perusahaan diharapkan mampu mendapatka tambahan dana yang disesuaikan dengan kebutuhan. Jumlah besar kecilnya dana obligasi bisa disesuaikan dengan kinerja keuangan perusahaan misalnya jumlah aliran kas perusahaan, jumlah hutang yang ada serta kemampuan pembayaran bunga obligasi dan pelunasan pokok obligasi pada saat jatuh tempoh, juga disesuaikan dengan prospek dari industri bisnis perusahaan dimasa mendatang.

Dibandingkan dengan mengajukan pinjaman dana ke bank,keputusan besarnya pinjaman biasanya disesuaikan dengan nilai jaminan (collateral) yang dimiliki perusahaan. Sedangkan menerbitkan obligasi tidak memberikan jaminan, hal ini menjadi daya tarik bagi perusahaan. Dengan menerbitkan obligasi, pihak perusahaan akan lebih fleksibel menentukan besar kecilnya dana yang dibutuhkan sesuai dengan kemampuan pasar (investor) dalam menyerap penerbitan obligasi tersebut serta kemampuan pihak penjamin emisi dalam memberikan komitmen jumlah penerbitan obligasi.

b. Mendapatkan pinjaman dengan tingkat suku bunga fleksibel

Pihak perusahaan yang menerbitkan obligasi akan mendapatkan dana tambahan dengan tingkat suku bunga yanng lebih fleksibel. Tingkat penentuan suku bunga (kupon) obligasi ditentukan berdasarkan kemampuan keuangan perusahaan serta memperhatiakan kondisi tingkat suku bunga di perbankan. Dibandingkan dengan meminjam dana dari perbankan, penentuan tingkat suku bunga cenderung berpihak pada kepentingan kreditur (bank). Sedangkan apabila menerbitkan obligasi, proses penentuan tingkat suku bunga relatif fleksibel disesuaikan dengan kemampuan dan kepentingan penerbit obligasi.

c. Mendapatkan alternatif pembiayaan melalui pasarmodal

Seperti diketahui, obligasi juga termasuk jenis hutang jangka panjang perusahaan yang kesulitan melakukan pinjaman melalui perbankan bisa mencari alternatif perusahaan melalui pasar modal dengan menerbitkan obligasi sejumlah dana yang dibutuhkan.

\section{Struktur obligasi}

Untuk mengenal instrumen obligasi secara detail, maka harus diketahui pengertian berbagai struktur obligasi. Sebagai sebuah instrumen investasi dan keuangan, obligasi akan dianggap sebagi surat hutang apabila memenuhi berbagai persyaratan yang ditentukan dan diatur dalam struktur obligasi. Menurut (Sapto Rahardjo 2004:15)

a. Prinsipal

Harga obligasi ditentukan oleh hukum permintaan dan penawaran atas obligasi tersebut. Secara umum dalam proses penerbitan awal sebuah obligasi dapat ditentukan berapa jumlah penerbitnya kemudian disesuaikan dengan jumlah nominalnya.

Prinsipal adalah nialai hutang pokok pinjaman (kewajiban yang harus dibayar kembali pada saat jatuh tempo serta dipisahan dari jumlah pendapatan bunga. Secara umum istilah prinsipal dalam 
obligasi biasa dinamakan sebagai nilai nominal obligasi (face value) yang tercantum dalam sertifikat obligasi tersebut.

b. Harga obligasi

Harga obligasi merupakan struktur penting dalam instrumen obligasi. Pembentukan harga sebuah obligasi ditentukan oleh beberapa faktor diantaranya adalah :

1. Tingkat kupon

Kupon obligasi tersebut tinggi maka harga obligasi cenderung semakin meningkat. apabila tingkat kupon obligasi yang diberikan relatif kecil, harga obligasi cenderung turun karena daya tarik untuk investor tersebut sangat kecil.

2. Rating emiten

Obligasi yang mempunyai rating bagus cenderung diminati oleh investor dibanding obligasi yang ratingnya jelek.

3. Nilai obligasi

Penerbitan sebuah niali obligasi harus didasarkan juga pada seberapa besar nilai obligasi yang akan diterbitkan dan dijual kepasar perdagangan.

4. Periode jatuh tempo

Obligasi yang mempunyai periode jatuh tempo lebih lama maka akan semakin lebih tinggi tingkat resikonya nsehingga yieldyang didapatkan juga berbeda dengan obligasi yang umur jatuh temponya cukup pendek.

5. Likuiditas obligasi

Apabila obligasi yang dibeli mempunyai likuiditas cukup tinggi maka harga obligasi tersebut cenderung stabil dan meningkat. Oleh karena itu saat membeli obligasi hendaknya membeli obligasi yang likuid yaitu yang selalu diperdagangkan dipasar obligasi serta selalu diminati oleh investor.

6. Tipe obligasi

Tipe obligasi yang menarik serta penjaminan yang sangat bagus akan membuat harga obligasi cenderung meningkat.

c. PAR

Par adalah nilai $100 \%$ dari harga nominal obligasi. Setiap niali nominal obligasi pada mekanisme perdagangan dipasar ditentukan dalam satuan \% (presentase).

1. Harga $=100 \%$ at PAR yaitu harga obligasinya sesuai nilai nominal obligasi. Jika (bunga kupon = bunga pasar)

2. Harga $<100 \%$ at DISCONT yaitu harga obligasinya dibawah niali nominalnya. Jika ( bunga kupon < bunga pasar)

3. Harga $>100 \%$ at PREMIUM yaitu harga obligasinya diatas nilai nominalnya. Jika (bunga kupon > bunga pasar).

d. Kupon

Kupon adalah berupa pendapatan suku bunga yang akan diterima oleh pemegang obligasi sesuai perjanjian dengan penerbit obligasi tersebut. Jenis-jenis obligasi.

a. Obligasi dengan bunga tetap

Invetor mendapatkan pembayaran bunga tetap

b. Obligasi dengan bunga tidak tetap

Tingkat suku bunga dihitung berdasrkan variabel relatif dari rata-rata tingkat suku bunga deposito

c. Obligasi prepetual

Salah satu jenis obligasi yang tidak terbatas jangka waktunya

d. Obligasi tanpa bunga

Mempunyai karekteristik tidak memberikan pembayaran kupon dengan memberikan harga diskonto.

e. Jatuh tempo

Jatuh tempo adalah tanggal dimana nilai pokok obligasi tersebut harus dilunasi oleh penerbit obligasi. Yanh harus diingat dalam membahas faktor jatuh tempo suatu obligasi adalah semakin lama masa jatuh tempo obligasi, akan semakin tinggi resiko investas, karena semakin tinggi resionya dalam masa yang begitu lama, resiko semakin buruk. Oleh karena itu, periode jatuh tempo untuk obligasi perusahaan di Indonesia biasanya dibuat dalam jangka waktu 5 tahun saja. Berpa klausal jatuh tempo :

1. Term bonds

Obligasi ini mempunyai masa jatuh tempo yang pasti dalam waktu yng ditentukan

2. Obligasi serial

Obligasi ini mempunyai masa jatuh tempo yang berbeda-beda sesui jadwal yang ada

3. Obligasi konversi 
Pada saat jatuh tempo obligasi, pihak pemegang obligasi diberi hak untuk mengkonversi obligasinya ke saham apabila hal ini sangat menguntungkan secara komersial

4. Obligasi yang dapat ditebus

Obligasi ini memberikan hak kepada pihak perusahaan untuk mempercepat masa jatuh tempo sebelum waktunya.

Tabel Jenis Obligasi

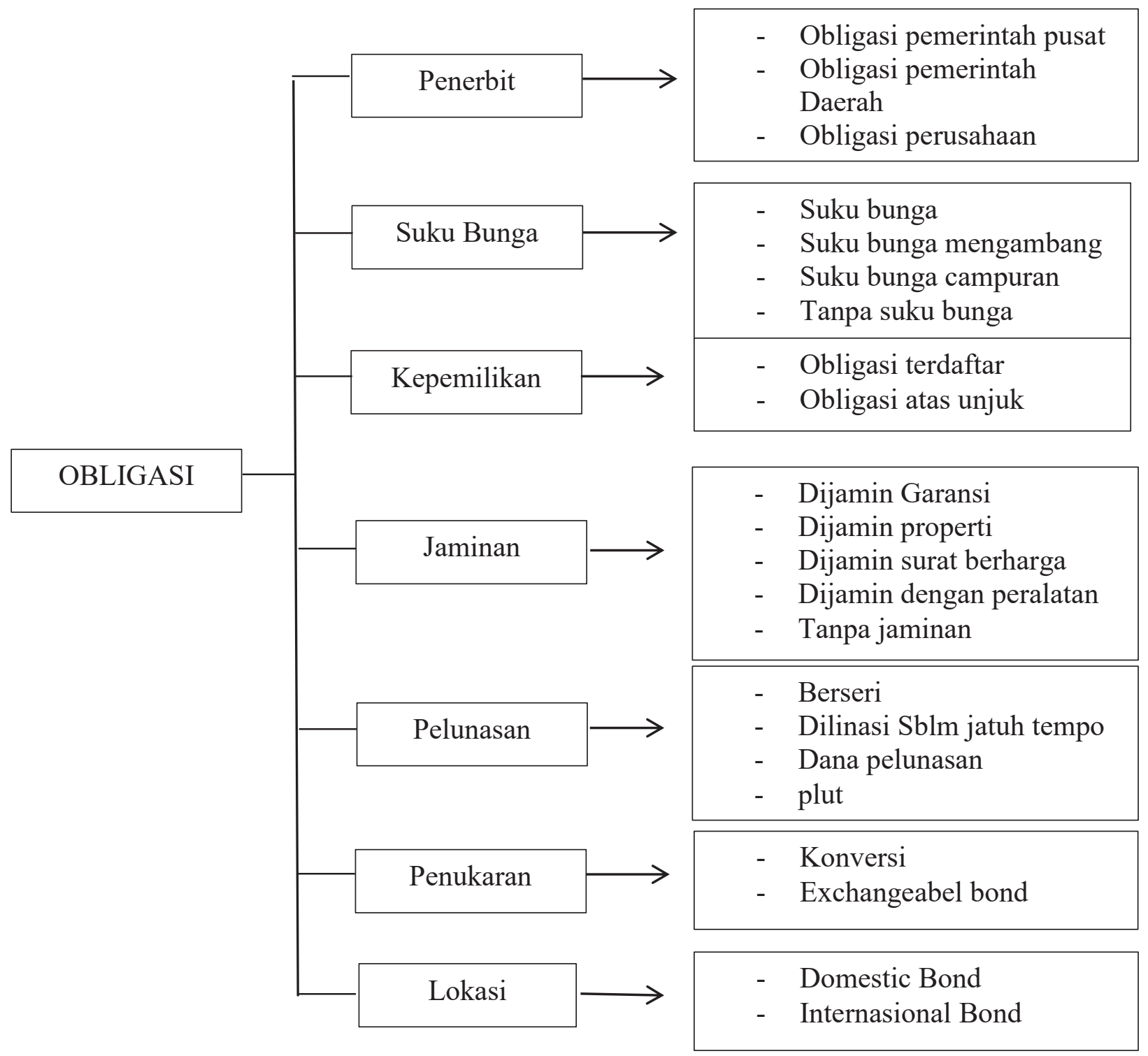

\section{Rating obligasi / Bond Rating Definisi bond rating}

Pemeringkatan obligasi (bond rating)adalah penilaian yang diberikan oleh lembaga pemeringkatan obligasi terhadap kualitas suatu obligasi yang diberikan oleh emiten. Terdapat perbedaan mengenai pengertian bond rating. Australian Ratings (1984) seperti yang dikutip oleh Prasetio, dkk dalam jurnal "Dampak pengumuman bond rating terhadap return saham perusahaan di Bursa Efek Jakarta" (2003: 686) menyatakan bahwa pemeringkatan hutang perusahaan memberikan sistem gradasi yang sederhana kepada para peminjam tentang kemampuan membayar bunga dan hutangnya dengan tepat waktu. Sedangkan PT PEFINDO menyatakan bahwa pada umumnya pemeringkatan hutang ( bond rating) merupakan indikator kemungkinan pembayaran bunga dan hutang tepat waktu sesuai dengan perjanjian yang telah disepakati. 


\section{Fungsi pemeringkatan hutang}

1. Sumber informasi superior terhadap kemampuan perusahaan, municipal atau pemerinta untuk membayar hutang dan bunga pinjaman. Superioritas dapat muncul dari kemampuan yang lebih besar untuk menganalisis informasi publik atau akses informasi konfidental. Contohnya beberapa perusahaan menutup informasi konfidental pemeringkat hutang pada kondiso konfiden.

2. Sumber informasi kredit berbiaya renda antar perusahaan, municipal dan pemerintah. Contohnya pengumpulan, proses dan pengikhtisaran informasi single agency yang dapat di interprestasikan dalam suatu format.

3. Sumber informasi legal bagi invesment trustee. Dengan membatasi investasi terhadap sekuritas hutang hanya dalam katagori highest rates, trustee dapat mengurangi pengungkapan kepada legal atas klaim karena kesalahan manajemen dalam menginvestasikan dannya.

4. Sumber sertifikasi keuangan tambahan dan respentasi manajemen lainya. Jika perusahaan pemeringkat hutang menetapkan pemeringkatan, maka reputasinya adalah resiko perusahaan yang diperingkat akan mempunyai dorongan untuk mengikuti perusahaan yang memeringkat sekuritas hutangnya sesuai dengan kelengkapan dan ketetapan waktu dari laporan keuangan dan data lain yang digunakan sebagai dasar untuk memeringkat. Dalam konteks ini perusahaan pemeringkat berjasa sebagai pemberi sertifikat kualitas informasi yang diberikan oleh pihak yang diperingkat sekuritas hutangnya.

5. Memonitor tindakan manajemen yaitu muncul karena adanya konflik antara pihak manajemn dengan pihak lain. Manajemen yang tidak berkeinginan melakukan tindakan yang menyimpang dari keinginan pemegang saham mempunyai dorongan untuk membentuk badan pemeringkat hutang . pembentukan itu sendiri merupakan sinyal bahwa manajemen menyiapkan diri untuk diekspos oleh pihak internal.

6. Memfasilitasil kebijakan publik yang membatasi investasi spekulatif atas instuisi, seperti bank, perusahaan asuransi dan dana pensiun. Biaya sosial dapat tinggi jika instuisi bangkrut, untukmengurangi resiko kemungkinan bangkrut, keberadaan perundangan dalam berapa negara yang mengatur tentang itu adalah penting. Maka implementasi kebijakan publik ini digunakan untuk memeringkat hutang sehingga mampu membedakan investasi spekulatif atau tidak.

\section{Manfaat rating bagi investor}

Dengan melakukan analisis dari segi keuangan atau manajemen dan bisnis fundamentalnya, setiap investor akan dapat menilai kelayakan bisnis usaha emiten tersebut. Selain itu, investor akan dapat menilai tingkat resiko yang timbul dariinvestasi obligasi tersebut. Beberapa manfaat rating bagi investor adalah sebagai berikut (Sapto Rahardjo, 2004: 100).

a. Informasi resiko investasi

Tujuan utama investasi adalah untuk meminimalkan resiko serta mendapatkan keuntungan yang maksimal.oleh karena itu, dengan adanya "peringkat obligasi" diharapkan informasi resiko dapat diketahui lebih jelas posisinya.

b. Rekomendasi investasi

Investor akan dengan mudah mengambil keputusan investasi berdasrkan hasil peringkat kinerja emiten obligasi tersebut. Dengan demikian investor dapat melakukan strategi investasi akan membeli atau menjual sesuai perencanaanya.

c. Perbandingan

Hasil rating akan menjadikan patokan dalam membandingkan obligasi yang satu dengan yang lainya, serta membandingkan struktur yang lain seperti suku bunga dan metode penjaminannya.

\section{Tujuan bond rating}

Obligasi sebagai salah satu produk investasi, selain memberikan keuntungan juga menimbulkan kerugian atas investasi tersebut. Untuk mengurangi resiko tersebut diperlukan pihakketiga sebagaipenyedia informasi tentang kinerja keuangan, manajemen, bisnis dan kondisi industri emiten obligasi tersebut.

Pihak institusi yang memberian evaluasi dan penilaian atas kinerja emiten tersebut biasanya disebut Lembaga Pemeringkat (Rating Company), lembaga ini bertugas untuk melakukan evaluasidan analisis atas kemungkinan macetnya pembayaran surat hutang. Dengan tidak adanya konflik kepentingan serta didukung analisis yang tajam terhadap kualitas hutang perusahaan, hasil penilaian tersebut 
dikeluarkan dalam bentuk peringkat yang independen. Lembaga pemeringkat tingkat internasional yang sangat terkenal diantaranya adalah S\&P (Standard \& Poors) Coorperation serta Mood"s Investor. Sedangkan di Indonesia dikenal dengan nama PAFINDo (Pemeringkat Efek Indonesia).

Lembaga ini melakukan analisis terbaru mengenai kinerja surat hutang tersebut atas dasar asumsi yang relatif independen. Setiap laporan keuangan yang baru diterbitkan atau munculnya kejadian penting yang menyangkut perseroan seta bersifat materialdan berdampak bagi kemampuan pembayaran kewajiban hutang, akan mengubah posisi hasil peringkattersebut, begitu juga sebaliknya.

Tujuan utama proses rating (Rahardjo, 2003:99) adalah memberikan infoprmasi akurat mengenai kinerja keuangan, posisi bisnis industri perseroan yang menerbitkan surat hutang (obligasi) dalam bentuk peringkat kepada calon investor.

\section{Return saham \{Capital Gain(loos) + Deviden \}}

Return merupakan hasil yang diperoleh dari investasi yaitu hasil pengambilan yang akan diperoleh melalui selisisih dari harga peneutupan. Return memungkinkan seorang investor untuk membandingkan aktual atau keuntungan yang diperoleh dari berbagai saham pada tingkat pengambilan yang diinginkan. Disisilain, return memiliki peran yang sangat signifikan didalam menentukan nilai dari sebuah saham, melalui peran sangat signifikannya tersebut tidak salah bila dikatakan bahwa membicarakan mengenai nilai sebuah saham akan selalu berpusat pada Return ini. Agar tingkat return saham dapat ditentukan seorang pemegang saham ditentukan untuk melakukan analisis terhadap nilai sebuah saham.sebuah analisis yang memungkinkan seorang pemegang saham menentukan apakah harga sebuah saham telah ditetapkan wajar, terlalu rendah atau terlalu tinggi.

Return saham dapat dibedakan menjadi return yang sudah diterimah/realisasi menunjukan faktasesungguhnya dari return saham dimana dapat dihitung dengan data yang ada secara aktual. Return realisasi ini penting karena digunakansalah satu pengukur kinerja perusahaan dan juga berguna sebagai dasar penentuan return ekspetasi dan resiko dimasa datang. Return ekspetasi adalah return hutang diharpakan akan diperoleh investor dimasa mendatang dimana antara return realisasi yang sifatnya sudah terjadi, return ekspetasi sifatnya belum terjadi.

\section{Profil PT PEFINDO (Pemeringkat Efek Indonesia)}

PT PEFINDO (perseroan) didirikan dijakarta tanggal 21 Desember 1993, atas prakarsa Badan Pengawa Pasar Modal (BAPEPAM) dan Bank Indonesia (BI) selanjutnya, perseroan memperoleh ijin operasi dari BAPEPAM pada tanggal 13 Agustus 1994 melalui surat keputusan No. 39/PM-PI/1994. Fungsi PEFINDO adalah sebagai salah satu institusi pendukung pasar modal yang memberikan penilaian objektif, independen dan terpercaya terhadap surat hutang yang ditawarkan kepada masyarakat melalui peringkat resiko surat hutang. Dua kegiatan utama perseroan yaitu pemeringkatan dan jasa infomasi, tumbuh dengan cepat sejalan dengan kebutuhan pasar modal. Dalam hal pemeringkatan, perseroan telah melakukan pemeringkatan atas perusahaan ,obligasi , surat berharga komersial (CP), dan surat berharga berjangka menegah. Diharapkan dimasa mendatang perseroan dapat melakukan jenis pemeingkatan yang lebih beragam. Demikian pula, dengan kegiatan jasa informasi diharapkan dapat diperluas dan lebih ditingkatkan.

Independensi dan objektifitasnya merupakan dua faktor penting dalam menentukan hasil pemeringkat. Untuk itu, struktur kepemilikan perseroan telah dirancang sedemikian rupa sehingga tidak ada pemilik yang secara sepihak dapat mempengaruhi kegiatan operasi PT PEFINDO. Sampai saat ini , terdapat 103 pemegang saham perseroan yang terdiri antara lain Bursa Efek Jakarta dan Surabaya, dana pensiun, bank pemerintah, perusahaan asuransi dan sekuritas. Selain hal tersebut diatas PT PEFINDO juga merancang proses pemeringkatan melalui kajian yang berlapis, sehingga tidak seorang pun secara sepihak dapat menentukan peringkat yang ditetapkan.

Selain kegiatan pemeringkat, PT PEFINDO terus melakukan riset dalam berbagai bidang yang berkaitan dengan pasar modal dan utang. Produk riset dan informasi ini mencakup analisis perusahaan, industri, pasar dan perekonomian. Dalam upaya pengembangan dan perbaikan antadard kualitas pemeringkatan PT PEFINDO telah menjalin kerjasama dengan Standard\& poor's rating service (S \&P) dan terus berpartisipasi aktif dalam Association Of Credit Rating Agencies in Asia (ACRAA).

\section{Penilaian PT PEFINDO}

Penilaian PT PEFINDO dimaksudkan untuk memberikan indikasi dari kemungkinan dan kemampuan dari suatu perusahaan penerbit obligasi membayar kewajiban finansialnya sesuai dengan 
syarat-syarat yang telah disepakati. Proses penilaian ini meliputi analisis karakteristik industri, analisia posisi pasar, analisa manajemen analisis finansial. Berikut ini merupakan penjelasan dari syarat-syarat diatas :

1. Analisis karakteristik industri

Analisis karakteristik industri adalah penilaian sifat dari bisnis industri. Penilaian ini meliputi pertumbuhan permintaan dan siklus industri, struktur industri, kompetensi dari dalam industri, struktur penawaran bahan mentah, intensitas modal dan fluktuasi tingkat suku bunga. Dalam menilai resiko industri tertentu PT PEFINDO juga menganalisis peran dan kepentingan nasionaldari industri itu, kebijakan dan peraturan pemerintah yang berlaku mempengaruhi industri tersebut.

2. Analisis posisi pasar

PT PEFINDO mengevaluasi posisi perusahaan secara seksama dipasar. Analisis semacam ini menilai pasar-pasar yang menjadi target perusahaan (distribusi, geografis, segmentasi pasar). Produk perusahaan kemampuan untuk mempengaruhi harga, ketahanan terhadap persaingan, efisiensi dan struktur biaya, kontrol atas distribusi ketergantungan terhadap konsumen dan pemasok utama, produktifitas pekerja.

3. Analisis manajemen

Analisis manajemen dilakukan dengan menilitisecara seksama pelaksanaan dari perencanaan perusahaan, kejelasan strategi bisnis, kebijakan manajemen dan tindakan yang diambil perusahaan untuk mencapai tujuannya. Tidak kalah pentingnya adalahpemahaman tentang hubungan perusahaan induk dengan perusahaan anak, khususnya apabilaperusahaan tersebut merupakan salah satu anggota dari suatu group bisnis yang besar atau bisnis keluarga.

4. Analisis finansial

PT PEFINDO menilai filosofi dan kebijakan manajemen yang melibatkan resiko finansial. Para analisis PT PEFINDO akan meneliti hal-hal yang berkaitan dengan kebijakan akuntansi dan keuangan termasuk strategi ekspansi dan sikap terhadap pertumbuhan, debt laverage, prinsif konsolidasi, penilaian terhadap aset, metode depresiasi dan pinjaman atau cadangan kerugian yang dapat diterima (recivable losses reserve). Dalam analisis kinerja finansial itu sendiri, masalahmasalah yang meliputi pelaporan neraca, profitabilitas, asuransi, struktur pendanaan dan kecukupan modal, likuiditasdan perlindungan pendapat masa depan dianalisis secara seksama PT PEFINDO juga mengevaluasi pilihan pendanaan perusahaan yang berada dalam kondisi terancam. Dampak potensial yang mungkin timbul dari ketidaksesuaian juga dipertimbangkan , begitu juga rencana-rencana perusahaan yang memungkinkan terjadinya masalah.

Dalam menilai suatu efek hutang PT PEFINDO melakukan beberapa langkah dimana langkah tersebut dijelaskan. Langkah -langkah tersebut adalah pertama mengumumkan informasi , kedua adalah perusahaan penerbit (issuer) mengajukan permohonan kepada PT PEFINDO untuk dinilai. Suatu perusahaan (produk efek) supaya dapat diperingkat harus memenuhi syaratyang ditetapkan oleh rating agency. PT PEFINDO menetapkan syarat-syarat yaitu laporan keuangan (financial statement) harus sudah diaudit 5 tahun terakhir dengan ketentuan dua tahun terakhir mendapatkan opini wajar tanpa pengecualian (WTP) serta diaudit oleh akuntan publik yang terdaftar di BEPEPAM. Langka ketiga adalah menugaskan suatu tim analisis, yang mengulang kembali proses yang telah dilalui dalam keenam langka diatas. Lalu diadakan rapat komisi pemeringkatan. Langkah selanjutnya menginformasikan ke klien setelah klien mendapat informasi dari PT PEFINDO. Klien menyetujui apakah menolak atau menyetujui informasi tersebut. Jika klien menyetujui hasil pemeringkatan tersebut maka ratingdipublikasikan dan selanjutnya rating obligasi tersebut tetap domonitor. Untuk selanjutnya kerangka dapat dilihat pada proses pemeringkatan. 


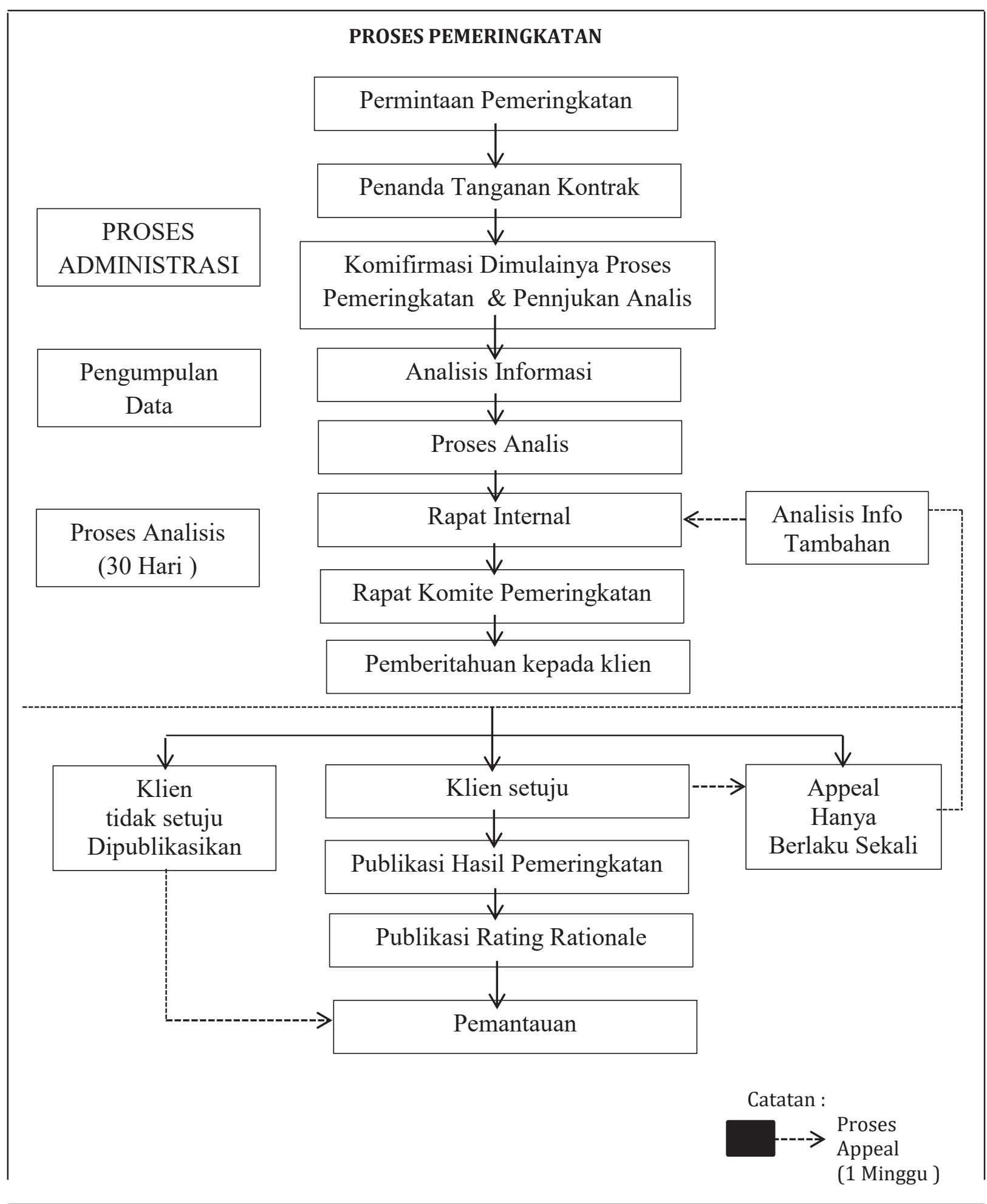

\section{Kategori Bond Rating}

Untuk mengantisipasi kebutuhan pasar, departemen keuangan , bapepam, dan Bank Indonesia pada tahun 1993 mempersiapkan terbentuknya PT PEFINDO sebagai lembaga pemeringkat pertama di Indonesia PT PEFINDO lahir pada tanggal 21 Desember 1993 melalui usulan BAPEPAM, Bank Indonesia, dimana Bacelius Ruru sebagai ketua pendirinya. Pada tahun1994 mendapatkan lisensi No. 39/PM/PI/1994 dari bapepam sebagai institusi resmi dibidang pemeringkatan efek di Indonesia PT PEFINDO mempunyai afiliasi dengan lembaga pemeringkat internasional , yaitu S \& P (Standard \& poor) serta aktiv 
dalam kegiatan ASEAN Forum of Credit Rating Agensies (AFCRA) untuk meningkatkan jaringan dan kualitas produk pemeringkat. Pemegang saham PT PEFINDO memang sengaja di sebar dan tidak boleh ada pemegang saham mayoritas. Tujuannya untuk menjaga independen lembaga ini. Selain pemegang saham diatas, tim pendiri PT PEFINDO juga mengundang Asosiasi Leasing Indonesia (ALI), Asosiasi Perbankan Nasional, Dewan Asuransi Indonesia dan bank-bank pemerintah sebagai pemegang saham. Kepemilikan masing-masing tidak boleh melebihi $10 \%$.

Sebagai lembaga pemeringkat PT PEFINDO berkewajiban memberikan opini objektif, independen dan jujur mengenai tingkat resiko suatu efek hutang berdasarkan analisis yang mendalam serta memberikan penilaian perusahaan. Disamping itu PT PEFINDO juga menjalankan kegiatan tentang pasar modal baik kegiatan yang bersifat praktis maupun yang bersifat kebijakan.

\begin{tabular}{|c|c|c|}
\hline GRADE & GATEGORIES & $\begin{array}{r}\text { DEFINITION } \\
\end{array}$ \\
\hline Id AAA & Prime, maximum safety & $\begin{array}{l}\text { Obligasi yang resiko investasinya paling rendah } \\
\text { yang berkemampuan paling baik untuk } \\
\text { membayar bunga dan pokok hutang dari seluruh } \\
\text { kewajiban keuangannya sesuai yang } \\
\text { diperjanjikan. }\end{array}$ \\
\hline Id AA & High Grade, High Quality & $\begin{array}{l}\text { Obligasi yang resiko investasinya sangat baik } \\
\text { membayar bunga dan kewajiban keuangan yang } \\
\text { dijanjikan dan tidak mudah dipengaruhi oleh } \\
\text { perubahan yang merugikan. }\end{array}$ \\
\hline Id A & Upper Medium Grade & $\begin{array}{l}\text { Obligasi yang resiko investasinya rendah } \\
\text { berkemampuan sangat baik untuk membayar } \\
\text { bunga dari kewajiban keuangan yang dijanjikan } \\
\text { dan hanya sedikit dipengaruhi oleh keadaan yang } \\
\text { merugikan. }\end{array}$ \\
\hline Id BBB & Lower Medium Grade & $\begin{array}{l}\text { Obligasi yang resiko investasinya cukup rendah } \\
\text { dan berkemampuan cukup baik dalam membayar } \\
\text { kewajiban meskipun kemampuannya tersebut } \\
\text { cukup peka terhadap keadaan yang merugikan. }\end{array}$ \\
\hline Id BB & $\begin{array}{l}\text { Non Investment Grade } \\
\text { Speculative }\end{array}$ & $\begin{array}{l}\text { Obligasi yang masih berkemampuan untuk } \\
\text { membayar kewajiban sesuai yang diperjanjikan } \\
\text { namun resiko investasi cukup tinggi dan sangat } \\
\text { peka terhadap keadaan yang merugikan. }\end{array}$ \\
\hline Id B & High Speculative & $\begin{array}{l}\text { Obligasi yang beresiko investasi cukup tinggi dan } \\
\text { berkemampuan sangat terbatas untuk } \\
\text { membayarbunga dan kewajibannya. }\end{array}$ \\
\hline Id CCC & $\begin{array}{l}\text { Substantion Risk in Poor } \\
\text { Standing }\end{array}$ & $\begin{array}{l}\text { Obligasi yang tidak berkemampuan lagi untuk } \\
\text { memenuhi segala kewajiban keuangannya }\end{array}$ \\
\hline Id D & Default & $\begin{array}{l}\text { Obligasi dengan peringkat ini, efek hutang yang } \\
\text { macet atau emitenya sudah berhenti usaha. }\end{array}$ \\
\hline
\end{tabular}

Sumber :PT PEFINDO, www.indoexchange.com

Catatan : Tanada tambah ( + ) atau kurang ( - ) dapat dicantumkan dengan peringkat dari AAA ( misal AAA) hingga CCC ( CCC+ / CCC-). Tanda tambah menunjukan bahwa suatu kategori peringkat lebih mendekati peringkat yang diatasnya. Tanda kurang berarti bahwa suatu kategori peringkat tetap lebih baik dari kategori peringkat di bawahnya, walaupun semakin mendekati.

Rating outlook PT PEFINDO merupakan penilaian atas prospek jangka menegah dan jangka panjang atas entitas dari / atau efek hutang yang diperingkat yang mencakup penilaian atas potensi perubahan keadaan perekonomian dan bisnis yang mendasar.

Definisi rating outlook menurut PT. PEFINDO

1. Positive yaitu prospek yang berpotensi untuk menigkatkan peringkat.

2. Negative yaitu prospek yang berpotensi untuk menurunkan peringkat.

3. Stable yaitu indikasi yang stabil sehingga hasil pemeringkatan juga stabil.

4. Developing yaitu prospek yang belum jelas karena keterbatasan informasi, sehingga hasil pemeringkatan juga dapat dinaikan atau diturunkan sesuai dengan perkembangan selanjutnya. 


\section{Saham}

\section{Pengertian Saham}

Dalam transaksi jual beli di Bursa Efek, saham atau sering disebut pula dengan shares merupakan instrumen yang paling dominan diperdagangkan. Suatu perusahaan dapat menjual hak kepemilikannya dalam bentuk saham (Stock). Wujud saham adalah selembar kertas yang menerangkan bahwa pemilik perusahaan yang menerbitkan kertas tersebut.

Menurut Drs. Abdul Basith ( kuliah ke 6 hal 34) "saham adalah bukti penyertaan suatu pihak atas suatu perusahaan / perseroan, dan dicatat dalam modal disetor". Menurut Dhalan Siamat (2011: 268) "saham atau stock adalah surat bukti atau tanda kepemilikan bagian modal pada suatu Perseroan Terbatas". Menurut Sawidji Widoatmodjo (2004 :83) "saham adalah surat berharga yang menyatakan bahwa pemiliknya menpunyai andil dalam memodali perusahaan”.

\section{Jenis saham}

Ada dua jenis saham yaitu :

1. Common stock

Common stock atau saham biasa adalah saham yang bersifat pemberian devidenya tidak tentu, dalam arti bahwa besar deviden yang dibagikan tergantung bagaimana keuntungan yang diperoleh perusahaan penerbitnya. Jika emiten sebagai perusahaan penerbit saham sedang berada pada posisi gemilang dan sanggup memperoleh laba besar. Tentu saja pemegang saham akan turut menikmati deviden yang besar pula sesuai dengan porsi jumlah saham yang dimilikinya.

2. Preferred stock

Preferred stock atau saham preferen adalah saham yang bersifat pemberian devidenya bisa disepakati antara investor dengan perusahaan penerbit saham. Deviden akan ditetapkan terlebih dahulu melalui perjanjian penetapan penerimaan deviden dan besarnya deviden biasanya tetap. Tetapi seandainya perusahaan sedang jatuh, pemilik saham preferen akan dinomor duakan dari pemilik obligasi, tetapi dinomor satukan dari pemilik saham biasa.

\section{Kerangka Pemikiran}

Bagan kerangka pemikiran :

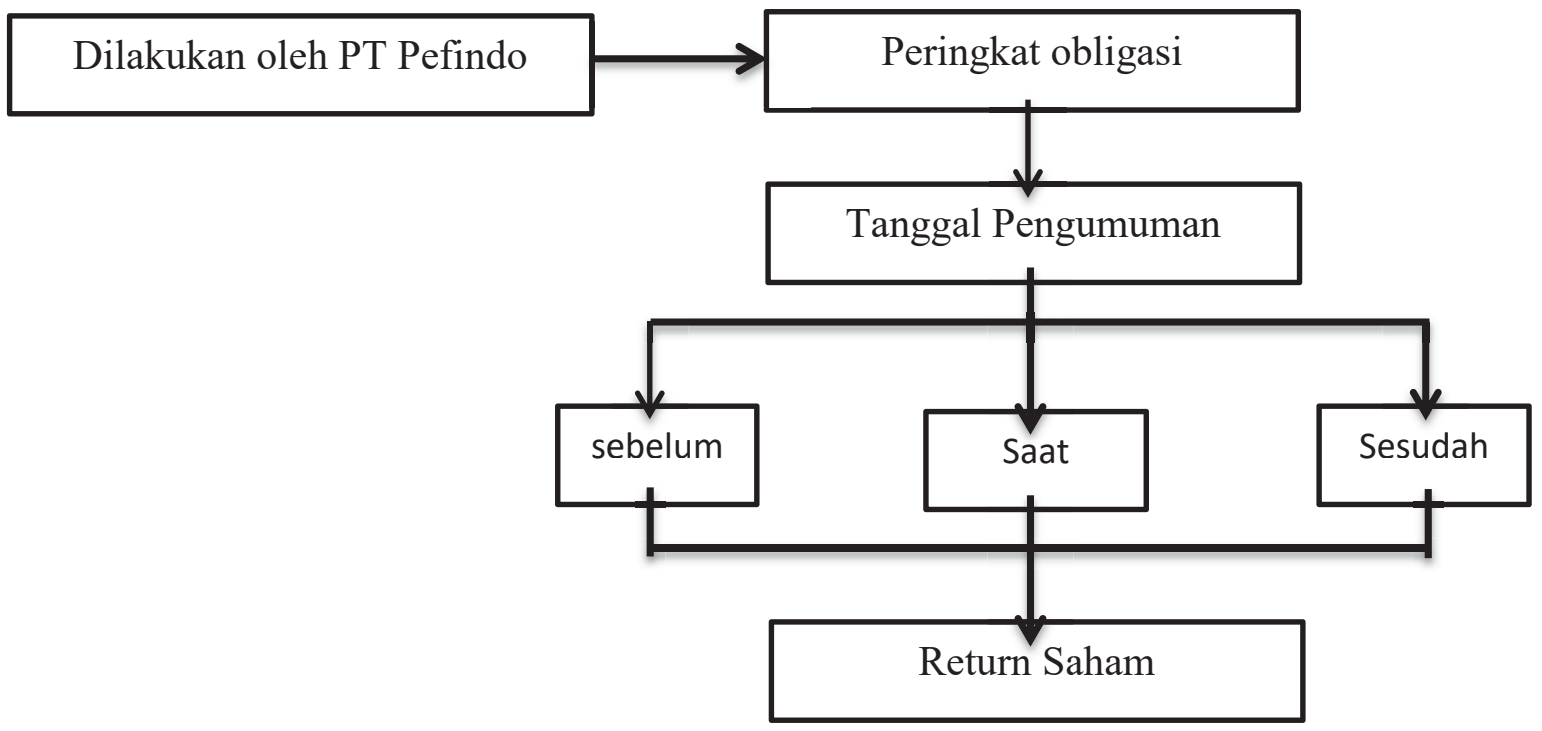

\section{Perumusan Hipotesis}

Hipotesis yang diajukan dalam penelitian ini adalah :

H1 : Ada perbedaan yang signifikan antara return saham pada tanggal pengumuman Bond Rating dengan hari-hari sebelum pengumuman.

H2 : Ada perbedaan yang signifikan antara return saham pada tanggal pengumuman Bond Rating dengan hari-hari sesudah pengumuman. 
H3 : Ada perbedaan yang signifikan antara return saham sebelum dengan sesudah pengumuman Bond Rating

H4 : Ada perbedaan yang signifikan antara return saham sebelum pengumuman, pada saat dan sesudah penumuman.

\section{ANALISIS DAN PEMBAHASAN \\ Statistik Deskriptif}

Dalam penelitian ini melakukan analisis dari tahun 2012 samapai tahun 2014 dimana terdapat 29 perusahaan yang melakukan pemeringkatan obligasi di PT PEFINDO dan mempunyai saham yang terdaftar di Bursa Efek Jakarta.

Tabel Daftar pengumuman bond rating perusahaan tahun 2012-2014

\begin{tabular}{|c|c|c|c|}
\hline No & IssueName & Tanggal Pengumuman & Rating \\
\hline 1 & PT. Telkom, Tbk & 14 Mei 2012 & AAA \\
\hline 2 & PT. Indosat, Tbk & 15 Oktober 2012 & $\mathrm{AA}+$ \\
\hline 3 & Berlian Taju Tanker, Tbk & 28 Mei 2012 & $\mathrm{~A}$ \\
\hline 4 & Metro Data Elektronik & 18 Desember 2012 & A \\
\hline 5 & PT. Dynaplast, Tbk & 5 Agustus 2012 & $\mathrm{~A}$ \\
\hline 6 & Aneka Tambang (Persero), Tbk & 30 September 2012 & $\mathrm{AA}$ \\
\hline 7 & Bank NISP & 12 Desember 2013 & BBB \\
\hline 8 & Bank Panin & 23 April 2013 & $\mathrm{BBB}+$ \\
\hline 9 & Bank Bumi Putera Indonesia, Tbk & 21 Februari 2013 & BBB- \\
\hline 10 & Bank Buana Indonesia, Tbk & 6 November 2013 & $\mathrm{BBB}+$ \\
\hline 11 & Bank Mandiri & 19 September 2013 & A- \\
\hline 12 & Clipan Finance Indonesia, Tbk & 17 Oktober 2013 & BBB \\
\hline 13 & Panin Securitas, Tbk & 27 Juni 2013 & BBB \\
\hline 14 & Bhakti Investama, Tbk & 25 Juli 2013 & BBB \\
\hline 15 & Astra Graphia, Tbk & 14 Agustus 2013 & A- \\
\hline 16 & Indonesia Visual Mandiri, Tbk & 29 Mei 2013 & A- \\
\hline 17 & Bank Negara Indonesia, Tbk & 20 Agustus 2014 & A- \\
\hline 18 & Bank Rakyat Indonesia & 12 November 2014 & $\mathrm{~A}$ \\
\hline 19 & Bank Danamon & 6 Mei 2014 & + \\
\hline 20 & Adira Dinamika Multi Finance & 27 Mei 2014 & A- \\
\hline 21 & Trimegah, Tbk & 13 Mei 2014 & A- \\
\hline 22 & Surya Citra Televisi & 25 Juni 2014 & $\mathrm{~A}-$ \\
\hline 23 & Alfa Retalindo, Tbk & 3 September 2014 & A- \\
\hline 24 & Medco Energi Internasional, Tbk & 2 Juni 2014 & AA- \\
\hline 25 & Adhi Karya (Persero) & 7 Juni 2014 & BBB \\
\hline 26 & Astra Agro Lestari, Tbk & 18 Februari 2014 & $\mathrm{~A}+$ \\
\hline 27 & Tunas Baru Lampung & 6 Januari 2014 & BBB \\
\hline 28 & Summaercon Agung, Tbk & 4 November 2014 & BBB \\
\hline 29 & Unggul Indah Cahata, Tbk & 4 November 2014 & A- \\
\hline
\end{tabular}

\section{Analisis Data dan Pengujian Hasil uji hipotesis Pengujian Normalitas}

Uji normalitas
Ho : Data berasal dari populasi normal
Ha : Data berasal dari populasi tidak normal

Pengambilan keputusan berdasarkan probabilitas :

Jika P- Value $>0,05$, maka Ho diterima.

Jika P- Value $<0,05$, maka Ho di tolak.

Tabel Rangkuman Hasil Pengujian Uji Normalitas dengan menggunakan Uji Kolmogorov - Smirnov Test.

\begin{tabular}{|l|l|l|}
\hline \multicolumn{1}{|c|}{ Variabel } & \multicolumn{1}{c|}{ Sig. } & \multicolumn{1}{c|}{ Kesimpulan } \\
\hline Return pada tanggal bond rating & 0,028 & Ho ditolak \\
\hline Return sebelum bond rating & 0,089 & Ho diterima \\
\hline Return sesudah bond rating & 0,743 & Ho diterima \\
\hline
\end{tabular}

Berdasarkan hasil output SPSS diketahui bahwa P-value return pada tanggal bond rating sebesar 0,028 lebih kecil dari 0,05, maka Ho ditolak yang berarti data berasal dari populasi tidak normal.sedangkan 
p-value return sebelum bondrating sebesar 0,089 lebih besar dari 0,05, maka Ho diterima yang berarti data yang berasal dari populasi normal dan p-value return sesudah bondrating sebesar 0,743 lebih besar dari 0,05, maka Ho diterima yang berarti data berasal dari populasi normal sehingga dapat melakukan uji hipotesis.

\section{Penguji Hipotesis Pertama}

Untuk menguji apakah pengumuman bond rating mempunyai kandungan informasi yang berpengaruh terhadap perubahan return saham diseputar tanggal pengumuman khususnya 15 (lima belas) hari sebelum tanggal pengumuman, digunakan studi peristiwa dengan alat analisis paired sampel ttest (uji t). Pengujian dilakukan untuk melihat apakah ada perbedaan yang signifikan antara return saham pada tanggal pengumuman bond rating dengan hari-hari sebelum pengumuman bond rating.

Dengan demikian hasil pengumuman terhadap return saham sebelum pengumuman dan pada saat pengumuman bond rating menunjukan bahwa rata-rata return saham pada saat pengumuman lebih tinggi dari pada ratairata return saham sebelum pengumuman bond rating.

Hipotesis pertama adalah

Ho1 : Tidak ada perbedaan yang signifikan antara return saham pada tanggal pengumuman bond rating dengan hari-hari sebelum pengumuman.

Ho2 : Ada perbedaan signifikan antara return saham pada tanggal pengumuman bond rating dengan hari-hari sebelum pengumuman.

Pengambilan keputusan berdasarkan ;

1. Berdasarkan probabilitas

Jika P-value $>0,05$, maka Ho diterima (tidak ada perbedaan yang signifikan)

Jika P-value $<0,05$, maka Ho ditolak (tidak ada perbedaan yang signifikan)

Dari tabel diatas dapat diketahui bahwa hasil uji paired sample $t$ tes yang dilakukan pada varibel return saham, rata-rata sebelum pengumuman menunjukan tingkat signifikannya (P-value) sebesar 0,611 yang berarti bahwa P-value > 0,05 maka Ho diterima dan Ha ditolak. Hasil penelitian ini menunjukan bahwa tidak ada perbedaan yang signifikan antara return saham pada tanggal pengumuman bond rating dengan hari-hari sebelum pengumuman bond rating.

Hal ini mengidentifikasikan bahwa pengumuman bond rating tidak memberikan kandungan informasi yang menguntungkan bagi investor. Meskipun terjadi perubahan terhadap rata-rata return sebelum pengumuman bond rating dengan rata-rata return saham pada saat pengumuman bond rating tetapi perbedaan tersebut tidak signifikan, sehingga hipotesis penelitian ini tidak mampu didukung. Analisis uji t 15 hari sebelum

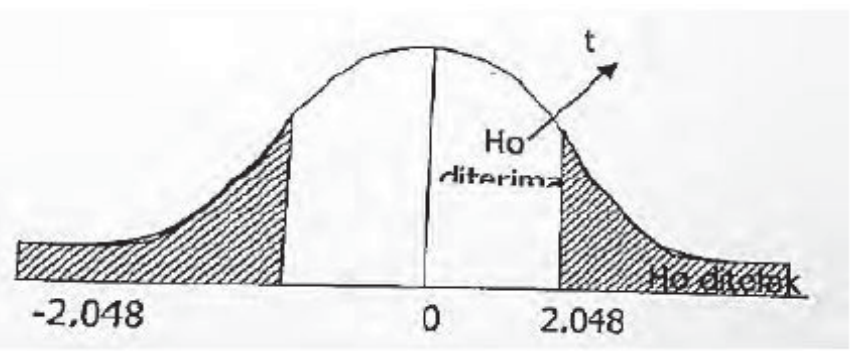

Berdasarkan dari tabel di atas diketahui bahwa t-hitung sebesar 0,542 berada di daerah Ho diterima atau t-hitung < dan t-tabel maka Ho diterima. Yang berarti tidak ada perbedaan yang signifikan return saham pada tanggal pengumuman bond rating dengan hari-hari sebelum pengumuman.

2. Pengujian Hipotesis kedua

Untuk menguji hipotesis apakah pengumuman bond ratingmempunyai kandungan informasi yang berpengaruh terhadap perubahan return saham di seputar tanggal pengumuman khususnya 15 (lima belas) hari sesudah tanggal pengumuman dilakukan pengujian dengan menggunakan paired sample $\mathrm{t}$ tabel (uji t) pengujian ini dilakukan untuk melihat apakah ada perbedaan yang signifikan 
antara return saham pada tanggal pengumuman bond rating dengan hari-hari sesudah pengumuman. Tabel menyajikan hasil rata-rata return saham untuk seluruh sample selam lima belas hari sesudah pengumuman, rata-rata sesudah pengumuman dan pada saat penggumuman bond rating.

Dengan melihat tabel di atas tersebut maka dapat dikatakan bahwa hasil pengujian terhadap return saham sesudah pengumuman dan pada saat pengumuman bond rating menunjukan rata-rata return saham pada saat pengumuman lebih tinggi dari pada rata-rata return saham sesudah pengumuman bond rating.

Tabel berikut ini menunjukan hasil pengujian hipotesis dua dengan uji t selama lima belas hari sesudah bond rating.

Pengambilan keputusan berdasarkan probabilitas :

Jika P-value $>0,05$, maka Ho diterima

Jika P-value $<0,05$, maka Ho ditolak

Hipotesis kedua adalah :

Ho2 :Tidak ada perbedaan yang signifikan antara return saham pada tanggal pengumuman bond rating dengan hari-hari sesudah pengumuman.

Ha2 : Ada perbedaan yang signifikan antara return saham pada tanggal pengumuman bond rating dengan hari-hari sesudah pengumuman.

Berdasrkan hasil uji paired sample t-test diketahui bahwa p-value sebesar 0,722 lebih besar dari 0,05 maka Ho diterima yang berarti tidak ada perbedaan yang signifikan antara return saham pada tanggal pengumuman bond rating dengan hari-hari sesudah pengumuman.

Analisa uji t 15 hari sesudah

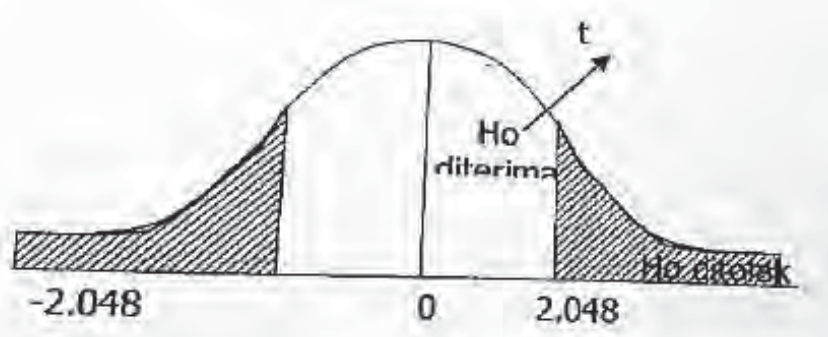

Berdasrkan tabel di atas diketahui bahwa thitung sebesar 0.039 berada di daerah Ho diterima atau t-hitung $<$ dari t tabel sebesar 2, 048, maka Ho diterima dengan demikian dari hasil uji t menunjukan bahwa tidak ada perbedaan yang signifikan antara retburn saham pada tanggal pengumuman bond rating dengan harihari sesudah pengumuman.

3. Pengujian hipotesis sebelum dengan sesudah pengumuman

Pengambilan keputusan berdasarkan probabilita :

Jika p- value $>0,05$ maka Ho diterima (tidak ada perbedaan yang signifikan)

Jika p-value $<0,05$ maka Ho ditolak ( ada perbedaan yang signifikan)

Ho : Tidak ada perbedaan yang signifikan antara return saham pada tanggal pengumuman bond rating dengan hari-hari sesudah pengumuman.

Ha : ada perbedaan signifikan antara return saham pada tanggal pengumuman bond rating dengan hari-hari sesudah pengumuman.

Dimana dalam pengujian hipotesis antara sebelum dengan sesudah tanggal pengumuman dimana tingkat signifikan sebesar 0,028. Dimana p-value $<0,05$ maka Ho ditolak berarti ada perbedaan yang signifikan antara sebelum da sesudah pengumuman bond rating.

\section{Paired Sample Statistic}

\begin{tabular}{|c|c|c|c|c|}
\hline & Mean & $\mathrm{N}$ & Stad Deviasi & Stdr eror Mean \\
\hline Rata-rata sebelum & -.002212 & 29 & .0011053555 & .002052594 \\
\hline Rata-rata sesudah & .00343800 & 29 & .006134685 & .001139182 \\
\hline
\end{tabular}




\section{Paired Sample Test}

\begin{tabular}{|l|c|c|c|c|c|c|}
\hline & Mean & $\begin{array}{c}\text { Stad } \\
\text { Deviation }\end{array}$ & Stad eror mean & $\mathrm{t}$ & $\mathrm{df}$ & $\begin{array}{c}\text { Sig } \\
(2 \text { tailed })\end{array}$ \\
\hline $\begin{array}{l}\text { Rata-rata sebelum - } \\
\text { Rata-rata sesudah }\end{array}$ & -.005650 & .013084194 & .002429674 & -2.325 & 28 & .028 \\
\hline
\end{tabular}

Pengujian hipotesis ketiga

Tabel Hasil Pengujian Hipotesis 3 dengan Anova

\begin{tabular}{|l|l|l|l|l|l|l|}
\hline Return saham & $\mathrm{N}$ & Mean & $\begin{array}{l}\text { Standar } \\
\text { deviasi }\end{array}$ & F & F.sig & Keterangan \\
\hline Sebelum & 29 & -.0022 & .01105 & & & Tidak \\
Saat & 29 & .0011 & .03458 & 0.517 & 0.598 & signifikan \\
Sesudah & 29 & .0034 & .00613 & & & \\
Total & 87 & .0008 & .02114 & & & \\
\hline
\end{tabular}

Hipotesis ketiga adalah :

Ho3 : Tidak ada perbedaan yang signifikan antara return saham sebelum pengumuman, pada saat pengumuman dan sesudah pengumuman bond rating.

Ha3 : Ada perbedaan yang signifikan antara return saham sebelum pengumuman, pada saat pengumuman dan sesudah pengumuman bond rating.

Pengambilan keputusan berdasarkan probabilitas

Jika p-value $<0,05$, maka Ho diterima (tidak ada perbedaan yang signifikan)

Jika p-value $<0,05$, maka Ho ditolak (ada perbedaan yang signifikan)

Berdasarkan hasil output SPSS diketahui bahwa p-value sebesar 0,598 maka Ho3 diterima yang berarti tidak ada perbedaan yang signifikan antara return saham sebelum pada tanggal pengumuman dan sesudah pengumuman bond rating.

Uji F

Berdasarkan F hitung Terhadap F tabel

Jika F hitung> F tabel, maka Ho ditolak

Jika F hitung < F tabel, maka Ho diterima

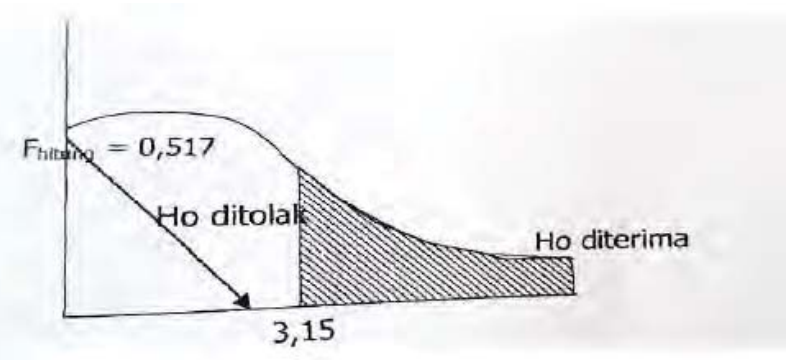

Berdasarkan tabel di atas diketahui bahwa F hitung sebesar 0, 517 dimana F hitung < F tabel, maka Ho diterima yang artinya tidak ada perbedaan yang signifikan antara return saham sebelum pada tanggal pengumuman dan sesudah pengumuman bond rating.

Pada pengujian hipotesis ketiga ini hasilnya sama dengan hipotesis pertama dan kedua menyatakan bahwa pengumuman bond rating tidak memberikan kandungan informasi bagi investor sehingga tidak mempengaruhi return saham secara signifikan.

\section{KESIMPULAN}

Dari analisis yang dilakukan oleh penulis diperoleh beberapa kesimpulan sebagai berikut :

1. Pengujian terhadap return saham sebelum dan pada saat pengumuman bond rating menunjukan bahwa rata-rata return saham pada saat pengumuman lebih besar dari pada rata-rata reurn saham sebelum pengumuman bond rating. Hasil dari uji t menunjukan bahwa tidak ada perbedaan yang signifikan antara return saham pada tanggal pengumuman bond rating dengan hari-hari sebelum pengumuman bond rating. Hal ini berarti hipotesis yang diajukan tidak berhasil di dukung.

2. Pengujian terhadap return saham sesudah dan pada saat bond rating menunjukan bahwa rata-rata return saham pada saat pengumuman lebih besar dari pada rata-rata reurn sesudah pengumuman. 
Dimana hasil uji t menunjukan bahwa tidak ada perbedaan yang signifikan antara return saham pada tanggal pengumuman bond rating dengan hari-hari sebelum dan sesudah pengumuman bond rating. Hal ini menunjukan bahwa hipotesis yang diajukan tidak berhasil didukung.

3. Pengujian terhadap return saham sebelum dan sesudah pengumuman bond rating dengan uji $t$ menunjukan bahwa ada perbedaan yang signifikan antara sebelum dan sesudah pengumuman bond rating.

4. Pengujian terhadap return saham sebelum, pada saat dan sesudah pengumuman bond rating menunjukan tidak ada perbedaan yang signifikan hipotesis penelitian ini tidak mampu didukung.

\section{Saran}

Dengan mengacu pada kesimpulan tersebut maka dapat diberikan saran-saran sebagai berikut :

1. Dalam melakukan investasi dengan memperjual belikan saham, selain memperhatikan faktor-faktor seperti informasi arus kas, laba perusahaa, jumlah kas deviden yang diberikan, tingkat suku bunga dan sebaiknya juga melihat pengumuman bond rating dan kondisi perekonomian yang terjadi agar dapat mengambil keputusan dengan baik dan lebih cepat.

2. PT fepindo sebagai suatu lembaga resmi yang independen, dalam memberikan suatu keputusan seharusnya tidak boleh dipengaruhi oleh emiten dan dalam melakukan riset untuk nenetapkan peringkat efek suatu perusahaan sebaiknya dilakukan secara hati-hati sehingga hasil peringkat yang dikeluarkan dapat lebih dipercaya oleh investor.

3. Untuk penelitian selanjutnya, perlu di uji pengaruh pengumuman bond rating terhadap return saham dengan mempertimbangkan kenaikan atau penurunan bond rating perusahaan sampel dan menguji waktunya agar lebih lama.

\section{DAFTAR PUSTAKA}

Ahmad, Kamaruddin. (2006). Dasar-Dasar Manajemen Investasi. Jakarta : Rineka Cipta

Anwar, Abdul Basith. (2004). Modul Kuliah Pasar Uang Pasar Modal. Jakarta

Fabozzi, Frank J.Franco Modigliani, Michael G Ferri. (2009). Pasar Dan Lembaga Keuangan. Buku Satu. New York : Prentice Hall intl.

Hermawan, Asep (2013). Pedoman Praktis Metodelogi Penelitian Bisnis. Jakarta : LPEE Universitas Trisakti. Husnan, Suad (2006). Dasar-Dasat Teori Portofolio Dan Analisis Investasi. Yogyakarta : UPP-AMP YKPN.

Idris, Irwan. (2009). Dilklat Kuliah Pasar Uang Pasar Modal. Jakarta : Jurusan Akuntansi Universitas Trisakti.

Jogiyanto H.M. (2013). Teori Portofolio Dan Analisis Investasi. Yogyakarta : BPFE.

Prasetio, Januar Ekon, Sri Astuti. (2013). Dampak Pengumuman Bond Rating Terhadap Return Saham Perusahaan Di Bursa Efek Jakarta. Surabaya : simposium nasional akuntansi IV.

Rahardjo, Sapto. (2004). Panduan Investasi Obligasi. Edisi Pertama. Jakarta :PT Gramedia Pustaka Utama.

Siamat, Dahlan. (2011). Manajemen Lembaga Keuangan. Edisi Ketiga. Jakarta : Fakultas Ekonomi Universitas Indonesia.

Santoso, singgih. (2010). Buku Latihan SPSS Statistik Parametik. Jakarta : Elexmedia Komputindo.

Sawidji, Widoatmojo. (2006). Cara Sehat Investasi Di Pasar Modal. Cetakan Kedua. Jakarta : PT Indo Aksara Grapfika.

Umar, Husain. (201 3). Metode Riset Bisnis . jakarta : PT Gramedia Pustaka Utama.

www.Pefindo.com

www.JSX.co,id

www.e-bursa.com

www.indoexchange.com 